Old Dominion University

ODU Digital Commons

\title{
The Power of Open: Benefits, Barriers, and Strategies for Integration of Open Educational Resources
}

Tian Luo

Old Dominion University

Kirsten Hostetler

Old Dominion University

Candice Freeman

Old Dominion University

Jill Stefaniak

Follow this and additional works at: https://digitalcommons.odu.edu/stemps_fac_pubs

Part of the Educational Assessment, Evaluation, and Research Commons

\section{Original Publication Citation}

Luo, T., Hostetler, K., Freeman, C., \& Stefaniak, J. (2020). The power of open: Benefits, barriers, and strategies for integration of open educational resources. Open Learning, 35(2), 140-158. doi:10.1080/ 02680513.2019.1677222

This Article is brought to you for free and open access by the STEM Education \& Professional Studies at ODU Digital Commons. It has been accepted for inclusion in STEMPS Faculty Publications by an authorized administrator of ODU Digital Commons. For more information, please contact digitalcommons@odu.edu. 
The Power of Open: Benefits, Barriers, and Strategies for Integration of Open Educational Resources

\section{Introduction}

In many countries such as the United States, access to affordable educational resources can be as significant a barrier to higher education entry as tuition. Students face the reality of purchasing course materials that have risen more than three times the rate of inflation since 1977 (Popken, 2015). Some forego the purchase of textbooks to the detriment of their academic performance. For others, this cost interferes with the ability to attain a degree, with the Advisory Committee on Student Financial Assistance estimating the high cost of course materials is one factor in keeping more than 2.4 million low- and moderate-income, college-qualified high school graduates from completing college (Advisory Committee on Student Financial Assistance, 2013). This increasing burden to college students gained attention and subsequent formal recognition in 2002 at a United Nations Educational, Scientific, and Cultural Organization (UNESCO) meeting. The final report from the Forum on the Impact of Open Courseware for Higher Education in Developing Countries coined the term Open Educational Resources (OER) to refer to the trend of sharing educational resources as a means of creating, utilizing, and repurposing reliable and purposeful educational content, with minimal or no limitations. The group adopted the following definition for OER: "The open provision of educational resources, enabled by information and communication technologies, for consultation, use, and adaptation by a community of users for non-commercial purposes" (UNESCO, 2002, p. 24). The expense of traditional text books as an obstacle is a powerful case for replacing traditional material with these open, shareable resources.

However, it is not an easy process to just remove one textbook and insert another, there are significant pedagogical issues to be considered prior to and after this transition. The time and effort it takes to make this change, especially when done without structural and institutional support, could be why the "open" approach has not fully disrupted the traditional publishing models. Despite vocal support among educators given the importance of reducing financial burdens on students, OER have yet to make the intended impact in higher education. We conducted a systematic literature review examining the advantages and disadvantages of OER to better understand this disparity. This review investigates how OER and its related practice are shaping the manner in which courses, curriculum, and instructional strategies are implemented at institutions of higher education across the globe. UNESCO predicted OER would serve as a "universal educational resource available for the whole of 
humanity" (UNESCO, 2002, p. 28). This review adds value to the literature by providing insights into the areas that may have prevented more widespread implementation and integration in higher education, and by identifying the gaps in current OER research, as well as alluding to directions for future research.

\section{Purpose of this Review}

The solution to rising costs in higher education will most likely be neither straightforward nor singular, but OER are often centered in the foreground of this conversation. This makes OER increasingly relevant to the future of education and instructional design. The purpose of this review is to explore strategies for OER adoption that promote efficient and effective design whilst also developing stakeholder and institutional support for OER programs. Our review's analysis was guided by the following questions:

1. What barriers exist that hinder or prevent OER adoption at institutions of higher education?

2. How do OER compare to non-open course materials in efficacy?

3. How can faculty better determine, choose, and prepare instructional strategies to integrate OER into courses?

\section{Methods}

\section{Selection Criteria}

To answer the research questions, a set of selection criteria were established and followed strictly:

1. Research should primarily focus on addressing barriers to the adoption, efficacy, and course integration of OER in the higher education setting. Studies that do not address these issues, or that are situated in other settings, such as $\mathrm{K}-12$, or professional development, were thus excluded;

2. Research must consist of empirical studies reporting data derived from actual observations or experimentations. Literature reviews, unpublished works, and conceptual articles were not included in the analysis.

3. Research must have been published in peer-reviewed, English-language, academic journals within the selected 10-year time frame (2009-2018). Papers published in non-peer-reviewed, non-English-language journals, or outside this time frame were excluded.

\section{Identification of Eligible Studies}

\section{Searching phase}


We began the process of identification of eligible studies by searching four major databases separately, Educational Research Information Center (ERIC), Education Research Complete (ERC), Academic Search Complete (ARC), and LearnTechLib. Keyword searches were conducted using the combinations of "open educational resources," "OER," "open access," "barriers," "efficacy," "perception," "strategies," "course integration," and "higher education." This round of search yielded 1,569 results in ERC, 123 in ERIC, 959 in ARC, and 158 in LearnTechLib. We identified 24 articles that met the selection criteria and were therefore included for further analysis.

A second round of search was conducted on Google Scholar to further expand the pool. Using the same keyword search, we reviewed the first 10 pages of results (approximately 195 results in total), and identified 13 more eligible articles to be included in the analysis. After removing duplicates, 37 articles remained in the pool.

\section{Screening phase}

We then carefully screened the current pool of articles to determine their eligibility. The screening process was performed through reading the abstracts of each article. Articles that did not contain empirical data, or did not touch upon OER within the higher education setting were excluded. Thirty-two articles remained eligible after the screening phase.

\section{Analysis phase}

We performed our analysis through full-text reading. We additionally removed seven articles that did not discuss the pertinent issues (barriers, efficacy and perception, and course integration) on OER in the higher education setting. Meanwhile, snowball sampling was conducted by examining related articles cited in the remaining 25 articles. Twenty-six more articles were found and added to the existing pool. This action resulted in an inclusion of a total of 51 articles from the analysis phase. All articles were organized and tabulated in alignment with the research questions for further analysis.

\section{Results}

\section{Barriers to Adoption}

Of the articles included for analysis, 18 met the selection criteria by addressing this review's first research question centering on institutional barriers to OER adoption. Table 1 provides a full summary of the relevant articles on this theme.

Table 1: Reviewed studies by category in regard to barriers $(n=18)$. 


\begin{tabular}{|c|c|c|c|c|}
\hline Author & Sample Size & Country & Category & Main Findings \\
\hline $\begin{array}{l}\text { Anderson, } \\
\text { Gaines, } \\
\text { Leachman, } \\
\text { Williamson } \\
(2017)\end{array}$ & $\begin{array}{l}N=266 \\
\text { engineering } \\
\text { faculty }\end{array}$ & USA & $\begin{array}{l}\text { Barriers, } \\
\text { institutional } \\
\text { support }\end{array}$ & $\begin{array}{l}\text { Best practices for the use of } \\
\text { OER as reported by faculty } \\
\text { from HEI: review available } \\
\text { OERs in the discipline; pursue } \\
\text { instruction opportunities if } \\
\text { knowledge regarding OERs is } \\
\text { limited; understand } \\
\text { departmental practices for the } \\
\text { adoption of course materials; } \\
\text { develop strong partnerships } \\
\text { with instructional designers, } \\
\text { curriculum coordinators, and } \\
\text { experts in copyright / } \\
\text { intellectual property }\end{array}$ \\
\hline $\begin{array}{l}\text { Chen, Panda } \\
\text { (2013) }\end{array}$ & $N=74$ & China & $\begin{array}{l}\text { Barriers; } \\
\text { discoverability; } \\
\text { integration; } \\
\text { selection }\end{array}$ & $\begin{array}{l}\text { This study was conducted in } \\
\text { the context of Chinese } \\
\text { distance education; barriers: } \\
\text { effective utilization of OER, } \\
\text { searching for content, } \\
\text { selection of OER, } \\
\text { understanding the impact of } \\
\text { copyright, and the effective } \\
\text { integration of OER within } \\
\text { instruction }\end{array}$ \\
\hline $\begin{array}{l}\text { Chiorescu } \\
\text { (2017) }\end{array}$ & $\begin{array}{l}N=159 \\
\text { US college } \\
\text { mathematics }\end{array}$ & USA & $\begin{array}{l}\text { Barriers; } \\
\text { computer- } \\
\text { assisted OER } \\
\text { application }\end{array}$ & $\begin{array}{l}\text { OER requiring aid of } \\
\text { computer-based applications } \\
\text { can pose significant } \\
\text { challenges if the hardware } \\
\text { and technology do not } \\
\text { support the software; } \\
\text { considerations should be } \\
\text { made when augmenting OER } \\
\text { with computer-based } \\
\text { applications }\end{array}$ \\
\hline $\begin{array}{l}\text { Coughlan, Pitt, } \\
\text { McAndrew } \\
(2013)\end{array}$ & $\begin{array}{l}N=20 \\
\text { community } \\
\text { colleges }\end{array}$ & $\begin{array}{l}\text { UK and } \\
\text { USA }\end{array}$ & $\begin{array}{l}\text { Barriers; } \\
\text { remixing }\end{array}$ & $\begin{array}{l}\text { Remixing has similar } \\
\text { challenges to using other } \\
\text { OER, discoverability of } \\
\text { remixed materials is difficult, } \\
\text { as are time barriers, } \\
\text { institutional culture; }\end{array}$ \\
\hline
\end{tabular}




\begin{tabular}{|c|c|c|c|c|}
\hline & & & & $\begin{array}{l}\text { understanding original } \\
\text { audience makes remixing } \\
\text { difficult }\end{array}$ \\
\hline $\begin{array}{l}\text { de Hart, } \\
\text { Chetty, } \\
\text { Archer } \\
(2015)\end{array}$ & $\begin{array}{l}N=3,800 \\
\text { academic } \\
\text { staff }\end{array}$ & $\begin{array}{l}\text { South } \\
\text { Africa }\end{array}$ & $\begin{array}{l}\text { Barriers; } \\
\text { adoption; } \\
\text { integration }\end{array}$ & $\begin{array}{l}\text { OER survey on adoption and } \\
\text { use: knowledge of OER, IP } \\
\text { and licensing, participation in } \\
\text { OER, and barriers to } \\
\text { participation in OER - study } \\
\text { participants were aware but } \\
\text { intermediate understanding of } \\
\text { copyright issues around use; } \\
\text { general lack of understanding } \\
\text { of intellectual property } \\
\text { practices; faculty search for } \\
\text { and use OER but few faculty } \\
\text { actually create and publish } \\
\text { OER for reuse }\end{array}$ \\
\hline $\begin{array}{l}\text { Dichev, } \\
\text { Bhattarai, } \\
\text { Clonch, } \\
\text { Dicheva } \\
\text { (2011) }\end{array}$ & $\begin{array}{l}N=13 \\
\text { computer } \\
\text { science } \\
\text { undergrads }\end{array}$ & USA & $\begin{array}{l}\text { Barriers; } \\
\text { discoverability }\end{array}$ & $\begin{array}{l}\text { Metadata is an essential } \\
\text { element, especially the } \\
\text { ability to upload derivatives } \\
\text { and have the various versions } \\
\text { connected in the repositories }\end{array}$ \\
\hline Friesen (2009) & $\begin{array}{l}N=16 \\
\text { OER } \\
\text { stakeholders }\end{array}$ & Canada & $\begin{array}{l}\text { Barriers; } \\
\text { sustainability }\end{array}$ & $\begin{array}{l}\text { Sustainability challenges; } \\
\text { awareness, usage, capacity } \\
\text { development specific to } \\
\text { application; change agents, } \\
\text { global usage, self-directed } \\
\text { and informal for intrinsically } \\
\text { motivated knowledge } \\
\text { acquisition and personal } \\
\text { enrichment, alignment, } \\
\text { benefit to the institution }\end{array}$ \\
\hline $\begin{array}{l}\text { Hassall, } \\
\text { Lewis (2017) }\end{array}$ & $\begin{array}{l}N=209 \\
\text { technical } \\
\text { faculty }\end{array}$ & $\begin{array}{l}\text { Indonesi } \\
\mathrm{a}\end{array}$ & $\begin{array}{l}\text { Barriers; } \\
\text { institutional } \\
\text { and technology }\end{array}$ & $\begin{array}{l}\text { OER adoption and use can be } \\
\text { enhanced by ongoing curation } \\
\text { of high quality resources; } \\
\text { greater institutional and } \\
\text { department support to } \\
\text { educators would benefit by } \\
\text { encouraging and allowing } \\
\text { instructors time to find and }\end{array}$ \\
\hline
\end{tabular}




\begin{tabular}{|c|c|c|c|c|}
\hline & & & & $\begin{array}{l}\text { incorporate effective OER } \\
\text { into their courses }\end{array}$ \\
\hline $\begin{array}{l}\text { Hew, } \\
\text { Cheung } \\
\text { (2013) }\end{array}$ & $\begin{array}{l}N=25 \\
\text { students }\end{array}$ & $\begin{array}{l}\text { Singapo } \\
\text { re }\end{array}$ & $\begin{array}{l}\text { Barriers; } \\
\text { application and } \\
\text { creation }\end{array}$ & $\begin{array}{l}\text { Students seek out OER for } \\
\text { their own needs but are not } \\
\text { willing to create and } \\
\text { produce OER for others to } \\
\text { use; lack of skills and } \\
\text { knowledge relating to } \\
\text { locating, using, and } \\
\text { creating OER }\end{array}$ \\
\hline $\begin{array}{l}\mathrm{Hu}, \mathrm{Li}, \mathrm{Li} \\
\text { Huang } \\
\text { (2015) }\end{array}$ & $\begin{array}{l}N=1,239 \\
\text { students }\end{array}$ & China & Barriers; usage & $\begin{array}{l}\text { Students familiar with } \\
\text { courses where OER } \\
\text { integrated but barriers } \\
\text { around digital interfaces, } \\
\text { environment or locale of } \\
\text { use can prevent optimal } \\
\text { access and utilization as } \\
\text { intended for the college } \\
\text { course }\end{array}$ \\
\hline $\begin{array}{l}\text { Mtebe, } \\
\text { Raisomo } \\
\text { (2014) }\end{array}$ & $\begin{array}{l}N=92 \\
\text { HEI } \\
\text { instructors }\end{array}$ & $\begin{array}{l}\text { Tanzani } \\
\text { a }\end{array}$ & $\begin{array}{l}\text { Barriers; } \\
\text { adoption }\end{array}$ & $\begin{array}{l}\text { Faculty have little time to } \\
\text { find and vet usable } \\
\text { resources, and lack the time } \\
\text { or drive to create OER }\end{array}$ \\
\hline $\begin{array}{l}\text { Murphy } \\
\text { (2013) }\end{array}$ & $\begin{array}{l}N=110 \\
\text { instructional } \\
\text { practitioners }\end{array}$ & UK & $\begin{array}{l}\text { Barriers; } \\
\text { adoption and } \\
\text { sustainability }\end{array}$ & $\begin{array}{l}\text { Lack of implementation of } \\
\text { OER contributed to lack of } \\
\text { institutional support, OER is } \\
\text { still in its pioneer stages of } \\
\text { creation and adoption, time } \\
\text { required to create and } \\
\text { implement OER }\end{array}$ \\
\hline $\begin{array}{l}\text { Ngimwa, } \\
\text { Wilson (2012) }\end{array}$ & $\begin{array}{l}N=3 \\
\text { case studies }\end{array}$ & $\begin{array}{l}\text { Kenya, } \\
\text { Uganda, } \\
\text { and } \\
\text { South } \\
\text { Africa }\end{array}$ & $\begin{array}{l}\text { Barriers; } \\
\text { readiness for } \\
\text { adoption }\end{array}$ & $\begin{array}{l}\text { Technological resources do } \\
\text { not necessarily hinder } \\
\text { adoption of OER and that the } \\
\text { challenges associated with } \\
\text { adoption are more related to } \\
\text { cultural, socioeconomic, and } \\
\text { institutional constraints and } \\
\text { policy }\end{array}$ \\
\hline $\begin{array}{l}\text { Okada, Barros } \\
\text { (2011) }\end{array}$ & $\begin{array}{l}N=1,243 \\
\text { open learning }\end{array}$ & $\begin{array}{l}\text { Brazil and } \\
\text { Portugal }\end{array}$ & $\begin{array}{l}\text { Barriers; } \\
\text { remixing }\end{array}$ & $\begin{array}{l}\text { Remixing materials helped } \\
\text { students learn content and } \\
\text { better connect with material; }\end{array}$ \\
\hline
\end{tabular}




\begin{tabular}{|c|c|c|c|c|}
\hline & $\begin{array}{l}\text { community } \\
\text { participants }\end{array}$ & & & $\begin{array}{l}\text { same difficulties with sharing } \\
\text { as with other open resources }\end{array}$ \\
\hline Panke (2011) & $\begin{array}{l}N=19 \\
\text { OER listserv } \\
\text { respondents }\end{array}$ & $\begin{array}{l}\text { Canada, } \\
\text { Iran, } \\
\text { Malaysia, } \\
\text { Mauritius, } \\
\text { Netherlan } \\
\text { ds, } \\
\text { Pakistan, } \\
\text { South } \\
\text { Africa, } \\
\text { Sweden, } \\
\text { UK and } \\
\text { USA }\end{array}$ & $\begin{array}{l}\text { Barriers; } \\
\text { sustainability }\end{array}$ & $\begin{array}{l}\text { Benefits: sharing, } \\
\text { repurposing; problems: } \\
\text { finding relevant content and } \\
\text { storing OER for future use; } \\
\text { informal vs. formal learning } \\
\text { environments - appears } \\
\text { when OER is used in an } \\
\text { informal manner, learning } \\
\text { happens with greater ease } \\
\text { and less effort; institutional } \\
\text { policy affects application }\end{array}$ \\
\hline $\begin{array}{l}\text { Robertson } \\
(2010)\end{array}$ & $\begin{array}{l}N=36 \\
\text { OER listserv } \\
\text { respondents }\end{array}$ & $\begin{array}{l}\text { UK, US, } \\
\text { Australia, } \\
\text { Belarus, } \\
\text { Brazil, } \\
\text { Canada, } \\
\text { Kenya, } \\
\text { Lituania, } \\
\text { Malawi, } \\
\text { Nigeria, } \\
\text { and South } \\
\text { Africa }\end{array}$ & $\begin{array}{l}\text { Barriers; } \\
\text { sustainability }\end{array}$ & $\begin{array}{l}\text { Distributed work model, } \\
\text { particularly with vested } \\
\text { partner like library, can help } \\
\text { reduce workload and } \\
\text { increase sustainability of } \\
\text { projects }\end{array}$ \\
\hline Rolfe (2012) & $\begin{array}{l}n_{1}=9 \\
\text { faculty } \\
n_{2}=50 \\
\text { staff }\end{array}$ & UK & $\begin{array}{l}\text { Barriers: } \\
\text { awareness and } \\
\text { attitudes } \\
\text { toward OER }\end{array}$ & $\begin{array}{l}\text { Lack of IT support and } \\
\text { confusion over copyright } \\
\text { issues create barriers for } \\
\text { many faculty; overall } \\
\text { positive attitude toward } \\
\text { OER and the willingness to } \\
\text { overcome the barriers will } \\
\text { continue to increase with } \\
\text { faculty adoption }\end{array}$ \\
\hline $\begin{array}{l}\text { Windle, } \\
\text { Wharrad, } \\
\text { McCormick, } \\
\text { Laverty, } \\
\text { Taylor } \\
(2010)\end{array}$ & $\begin{array}{l}N=1 \\
\text { case study }\end{array}$ & UK & $\begin{array}{l}\text { Barriers and } \\
\text { use; } \\
\text { institutional } \\
\text { support, } \\
\text { development, } \\
\text { sustainability }\end{array}$ & $\begin{array}{l}\text { Community, ownership, } \\
\text { and empowerment serve to } \\
\text { promote and can help to } \\
\text { sustain the creation, } \\
\text { adoption, and use of OER. } \\
\text { Case study indicates that } \\
\text { those who feel empowered } \\
\text { to confidently use OER }\end{array}$ \\
\hline
\end{tabular}




\begin{tabular}{|l|l|l|l|l|}
\hline & & & $\begin{array}{l}\text { will be more likely to } \\
\text { reuse, recommend, and } \\
\text { create OER. }\end{array}$ \\
\hline
\end{tabular}

These articles represent empirical studies that touched on general education uses of OER, not only as textbooks but also other course materials, multimedia, software, as well as entire open courses. A limited number of eligible studies focused on OER uses in specific disciplines, and those that did were concerned with the medical and health sciences field, and also education, and math (Hassall \& Lewis, 2017; Windle, Wharrad, McCormick, Laverty, \& Taylor, 2010; Hew \& Cheung, 2013; Chiorescu, 2017; Anderson, Gaines, Leachman, \& Williamson, 2017). Additionally, there have been significant, innovative, worldwide advancements in OER adoption, so it was important to address studies that represent international barriers as well, with more than $76 \%$ of articles included in this section representing international perspectives (Chen \& Panda, 2013; Coughlan, Pitt, \& McAndrew, 2013; de Hart, Chetty, \& Archer, 2015; Hassall \& Lewis, 2017; Hew \& Cheung, 2013; Hu, Li, Li, \& Huang, 2015; Mtebe \& Raisamo, 2014; Murphy, 2013; Okada \& Barros, 2011; Panke, 2011; Robertson, 2010; Rolfe, 2012; Windle et al., 2010).

Even across borders and applications, there were recurring themes in the included studies where faculty, students, and institutions struggled to embrace OER, even when the benefits of adoption were clear. In several studies, awareness was not a critical barrier as faculty and students knew the term and definitional concepts of open - it was moving beyond this basic understanding to more intermediate or advanced perceptions that served as an obstacle (de Hart et al., 2015; Hu et al., 2015; Rolfe, 2012). The first barrier that prevented greater experience with OER centered on discoverability. The difficulty in discoverability means that selection of appropriate material and integration into the course takes a substantial amount of time (de Hart et al., 2015). Faculty wanted to ensure they were finding quality open resources and locating OER was particularly difficult with siloed repositories that have inconsistent depths of coverage and incompatible or inadequate metadata (Chen \& Panda, 2013; Dichev, Bhattarai, Clonch, \& Dicheva, 2011).

Secondly, OER is increasingly being augmented with computer-based applications, but accessibility poses a challenge when students are asked to have consistent access to technology and this factor should be taken into consideration during the selection process (Chiorescu, 2017; Hassall \& Lewis, 2017). Challenges with accessibility are also understood as a difficulty in finding material licensed to permit derivative works (Amiel, 2013). Remixing is a particularly appealing affordance 
of many open materials, yet demands additional time investment to adapt materials.. Faculty also expressed uncertainty around copyright and procedures for sharing remixed materials (Coughlan et al., 2013; Hew \& Cheung, 2013; Ngimwa \& Wilson, 2012; Okada \& Barros, 2011). Having created the adaption, determining how to license the creation to ensure new audiences do not run into the same problem when attempting to remix can be an additional layer of challenge associated with remixing.

Lastly, the most frequently cited barrier in the literature was in regard to sustainability in adopting OER via institutional support (Anderson et al., 2017; Friesen, 2009; Hassall \& Lewis, 2017; Mtebe \& Raisamo, 2014; Murphy, 2013; Panke, 2011; Robertson, 2010; Windle et al., 2010). Studies repeatedly alluded to systemic burdens embedded within higher education institutions that make it difficult not only to start an OER initiative, but to continue it after initial funding runs out. For example, Friesen (2009) noted that a majority of OER initiatives are individual projects rather than large-scale curriculum redesigns. Such format of implementation narrows the work burden to individuals rather than sharing the load, and does not address cultural and structural barriers across an institution. Since sustainability is often a well recognized issue, one suggestion is that institutions should seek partnership opportunities on campus with those who already understand the culture and can make it easier for educators and designers. For example, libraries could be key in their wide connection to campus stakeholders, their understanding of cataloging and licensing, andtheir frontline knowledge of student difficulties in affording course materials (Robertson, 2010).

\section{Perception and Efficacy}

Most studies found in the literature and included in this review addressed the second research question regarding the quality of OER and its efficacy when integrated into courses. Twenty-two articles met this selection criteria and Table 2 provides an analysis of each of these.

Table 2: Reviewed studies by category in regard to efficacy and perception $(n=22)$.

\begin{tabular}{|l|l|l|l|l|}
\hline Author & Sample Size & Country & Category & Main Findings \\
\hline $\begin{array}{l}\text { Abramovich, } \\
\text { McBride }\end{array}$ & $\begin{array}{l}N=697 \\
\text { faculty and } \\
\text { students at } \\
\text { a } \\
\text { community } \\
\text { college }\end{array}$ & USA & $\begin{array}{l}\text { Perception } \\
\text { of } \\
\text { efficacy }\end{array}$ & $\begin{array}{l}\text { Students thought OER } \\
\text { course materials were } \\
\text { better/more useful than } \\
\text { traditional materials but that } \\
\text { they were of less financial } \\
\text { value; instructors felt OER } \\
\text { helped achieve course }\end{array}$ \\
& & & & \\
\hline
\end{tabular}




\begin{tabular}{|c|c|c|c|c|}
\hline & & & & $\begin{array}{l}\text { objectives frequently or } \\
\text { almost every time }\end{array}$ \\
\hline $\begin{array}{l}\text { Allen, } \\
\text { Guzman- } \\
\text { Alvarez, } \\
\text { Molinaro, } \\
\text { Larsen } \\
(2015)\end{array}$ & $\begin{array}{l}n_{1}=478 \\
n_{2}=448 \\
\text { chemistry } \\
\text { students }\end{array}$ & USA & Efficacy & $\begin{array}{l}\text { No statistical differences } \\
\text { existed between } \\
\text { experimental and control } \\
\text { groups, both in performance } \\
\text { and student attitudes }\end{array}$ \\
\hline $\begin{array}{l}\text { Allen, } \\
\text { Seaman } \\
\text { (2014) }\end{array}$ & $\begin{array}{l}N=3,006 \\
\text { faculty }\end{array}$ & USA & $\begin{array}{l}\text { Perception } \\
\text { of } \\
\text { efficacy }\end{array}$ & $\begin{array}{l}\text { Cost ranked important by } \\
\text { faculty all other things being } \\
\text { equal; awareness of OER is } \\
\text { still a significant barrier for } \\
\text { faculty adoption }\end{array}$ \\
\hline $\begin{array}{l}\text { Bliss, } \\
\text { Robinson, } \\
\text { Hilton, } \\
\text { Wiley } \\
\text { (2013) }\end{array}$ & $\begin{array}{l}n_{1}=96 \\
\text { students, } \\
n_{2}=240 \\
\text { student } \\
\text { scores }\end{array}$ & USA & Efficacy & $\begin{array}{l}83 \% \text { of students were } \\
\text { satisfied with open materials, } \\
87 \% \text { would recommend } \\
\text { OER to other students; } \\
\text { significant improvement in } \\
\text { test scores }\end{array}$ \\
\hline $\begin{array}{l}\text { Bowen, } \\
\text { Chingos, } \\
\text { Lack, } \\
\text { Nygren } \\
\text { (2012) }\end{array}$ & $\begin{array}{l}N=605 \\
\text { statistics } \\
\text { students }\end{array}$ & USA & Efficacy & $\begin{array}{l}\text { No significant difference } \\
\text { between those who } \\
\text { participated in open vs. } \\
\text { traditional, analysis of cost } \\
\text { savings to student }\end{array}$ \\
\hline $\begin{array}{l}\text { Clements, } \\
\text { Pawlowski } \\
\text { (2012) }\end{array}$ & $\begin{array}{l}N=146 \\
\text { educators }\end{array}$ & $\begin{array}{l}\text { (European } \\
\text { context) }\end{array}$ & $\begin{array}{l}\text { Perception } \\
\text { of } \\
\text { efficacy }\end{array}$ & $\begin{array}{l}\text { Faculty located OER } \\
\text { resources through } \\
\text { browsing/recommendations } \\
\text { from colleagues; faculty } \\
\text { opinion was that OER } \\
\text { compatibility to course } \\
\text { content and purpose was } \\
\text { challenging }\end{array}$ \\
\hline $\begin{array}{l}\text { Cronin } \\
(2017)\end{array}$ & $N=19$ & Ireland & Efficacy & $\begin{array}{l}\text { Support for collaboration and } \\
\text { full integration into the } \\
\text { course with professional } \\
\text { development opportunities } \\
\text { created a quality, equivalent } \\
\text { experience for faculty }\end{array}$ \\
\hline $\begin{array}{l}\text { Feldstein, } \\
\text { Martin, }\end{array}$ & $N=991$ & USA & $\begin{array}{l}\text { Perception } \\
\text { of }\end{array}$ & $\begin{array}{l}\text { Didn't have } 100 \% \text { adoption, } \\
\text { but } 85 \% \text { of students }\end{array}$ \\
\hline
\end{tabular}




\begin{tabular}{|c|c|c|c|c|}
\hline $\begin{array}{l}\text { Hudson, } \\
\text { Warren, } \\
\text { Hilton, } \\
\text { Wiley } \\
(2012)\end{array}$ & $\begin{array}{l}\text { business } \\
\text { students }\end{array}$ & & $\begin{array}{l}\text { efficacy; } \\
\text { efficacy }\end{array}$ & $\begin{array}{l}\text { downloaded materials after } 4 \\
\text { weeks into semester; survey } \\
\text { showed positive student } \\
\text { reaction; conducted initial } \\
\text { statistical comparison of } \\
\text { grades to other courses }\end{array}$ \\
\hline $\begin{array}{l}\text { Grewe, } \\
\text { Davis (2017) }\end{array}$ & $N=146$ & USA & Efficacy & $\begin{array}{l}\text { Utilization of OER } \\
\text { demonstrates a positive } \\
\text { impact on student } \\
\text { achievement and a higher } \\
\text { GPA at course completion }\end{array}$ \\
\hline $\begin{array}{l}\text { Harsasi } \\
(2015)\end{array}$ & $N=39$ & Indonesia & Efficacy & $\begin{array}{l}\text { Majority indicate quality of } \\
\text { OER for e-learning course } \\
\text { was satisfactory within } \\
\text { respect to information, visual } \\
\text { appeal, graphical content and } \\
\text { ease of access; difficulties in } \\
\text { remixing English OER for } \\
\text { cultural differences }\end{array}$ \\
\hline $\begin{array}{l}\text { Hilton III, } \\
\text { Gaudet, } \\
\text { Clark, } \\
\text { Robinson, } \\
\text { Wiley } \\
(2013)\end{array}$ & $\begin{array}{l}n_{1}=2,043 \\
\text { students, } \\
n_{2}=20 \\
\text { faculty }\end{array}$ & USA & $\begin{array}{l}\text { Perception } \\
\text { of } \\
\text { efficacy; } \\
\text { efficacy }\end{array}$ & $\begin{array}{l}\text { Students saved } \$ 255,375 \text { if } \\
\text { all enrolled used OER; those } \\
\text { who did reported materials } \\
\text { supported content, no } \\
\text { significant difference } \\
\text { between course completion } \\
\text { and success; faculty felt } \\
\text { OER supported the course } \\
\text { and felt able to remix } \\
\text { material }\end{array}$ \\
\hline $\begin{array}{l}\text { Hilton III, } \\
\text { Laman } \\
(2012)\end{array}$ & $\begin{array}{l}N=690 \\
\text { students }\end{array}$ & USA & Efficacy & $\begin{array}{l}\text { Compared adoption and use } \\
\text { to final exam scores, student } \\
\text { GPA, and student retention } \\
\text { rates; direct correlation to } \\
\text { carefully adopted OER and } \\
\text { student performance in } \\
\text { specific college courses }\end{array}$ \\
\hline $\begin{array}{l}\text { Hussain, } \\
\text { Chandio, } \\
\text { Sindher } \\
(2013)\end{array}$ & $\begin{array}{l}N=278 \\
\text { faculty in } \\
\text { higher } \\
\text { education }\end{array}$ & Pakistan & $\begin{array}{l}\text { Perception } \\
\text { of } \\
\text { efficacy }\end{array}$ & $\begin{array}{l}\text { Pakistani faculty perceive } \\
\text { OER promotes learning in } \\
\text { higher education and } \\
\text { facilitates research practices } \\
\text { and learning about }\end{array}$ \\
\hline
\end{tabular}




\begin{tabular}{|c|c|c|c|c|}
\hline & & & & $\begin{array}{l}\text { advancements in various } \\
\text { disciplines }\end{array}$ \\
\hline $\begin{array}{l}\text { Jung, Bauer, } \\
\text { Heaps } \\
\text { (2017) }\end{array}$ & $\begin{array}{l}N=150 \\
\text { faculty } \\
\text { adopting } \\
\text { OER from } \\
\text { OpenStax }\end{array}$ & $\begin{array}{l}\text { United } \\
\text { States, } \\
\text { Canada, } \\
\text { South } \\
\text { Africa, } \\
\text { Bosnia } \\
\text { Herzegovina, } \\
\text { Italy, and } \\
\text { Germany }\end{array}$ & $\begin{array}{l}\text { Perception } \\
\text { of } \\
\text { efficacy }\end{array}$ & $\begin{array}{l}\text { Faculty perceptions that they } \\
\text { dedicated the same amount } \\
\text { of time adopting OER as } \\
\text { traditional textbooks; little to } \\
\text { no change in their } \\
\text { instructional strategies; } \\
\text { students were equally } \\
\text { prepared with OER as with } \\
\text { traditional textbooks; and } \\
\text { students demonstrated the } \\
\text { same level of performance }\end{array}$ \\
\hline $\begin{array}{l}\text { Kaatrakoski, } \\
\text { Littlejohn, } \\
\text { Hood (2017) }\end{array}$ & $N=30$ & Europe & $\begin{array}{l}\text { Perception } \\
\text { of } \\
\text { efficacy }\end{array}$ & $\begin{array}{l}\text { Educators believed that it was } \\
\text { difficult to integrate OER into } \\
\text { conventional teaching practices; } \\
\text { runs the risk of not fully } \\
\text { maximizing the potential of } \\
\text { OER }\end{array}$ \\
\hline $\begin{array}{l}\text { Machado, } \\
\text { Sepúlveda, } \\
\text { Montoya } \\
(2016)\end{array}$ & $\begin{array}{l}N=21 \\
\text { students in } \\
\text { case study }\end{array}$ & Venezuela & $\begin{array}{l}\text { Perception } \\
\text { of } \\
\text { efficacy }\end{array}$ & $\begin{array}{l}\text { In OER adoption, } \\
\text { developing partnerships can } \\
\text { help ensure that faculty are } \\
\text { bought into adoption and its } \\
\text { effective use }\end{array}$ \\
\hline $\begin{array}{l}\text { McKerlich, } \\
\text { Ives, } \\
\text { McGreal } \\
(2013)\end{array}$ & $\begin{array}{l}N=90 \\
\text { faculty in } \\
\text { higher } \\
\text { education }\end{array}$ & Canada & Efficacy & $\begin{array}{l}\text { Less than half of the faculty } \\
\text { are using OER, and less than } \\
\text { one-third of that half create } \\
\text { OER; creation: use ratio may } \\
\text { be a good metric for the } \\
\text { resource course efficacy }\end{array}$ \\
\hline $\begin{array}{l}\text { Pitt, } \\
\text { Ebrahimi, } \\
\text { McAndrew, } \\
\text { Coughlan } \\
\text { (2013) }\end{array}$ & $\begin{array}{l}n_{1}=490 \\
\text { students, } \\
n_{2}=58 \\
\text { teachers }\end{array}$ & USA & $\begin{array}{l}\text { Perception } \\
\text { of } \\
\text { efficacy }\end{array}$ & $\begin{array}{l}\text { Teachers reported having to } \\
\text { spend more time on prep to } \\
\text { accommodate OER use but } \\
\text { felt students were more } \\
\text { prepared, majority of } \\
\text { students/teachers saw OER } \\
\text { of equal or greater quality }\end{array}$ \\
\hline $\begin{array}{l}\text { Schuwer, } \\
\text { Mulder } \\
\text { (2009) }\end{array}$ & $N=980$ & Netherlands & $\begin{array}{l}\text { Perception } \\
\text { of } \\
\text { efficacy }\end{array}$ & $\begin{array}{l}\text { Language barriers cause } \\
\text { issues with remixing; } \\
\text { learners report errors }\end{array}$ \\
\hline
\end{tabular}




\begin{tabular}{|l|l|l|l|l|}
\hline $\begin{array}{l}\text { Vojtech, } \\
\text { Grissett } \\
(2017)\end{array}$ & $\begin{array}{l}\text { N=23 US } \\
\text { college } \\
\text { students }\end{array}$ & USA & $\begin{array}{l}\text { Perception } \\
\text { of } \\
\text { efficacy }\end{array}$ & $\begin{array}{l}\text { Students consider faculty } \\
\text { who use OER to be more } \\
\text { considerate of student needs } \\
\text { with regard to textbook cost }\end{array}$ \\
\hline $\begin{array}{l}\text { Watson, } \\
\text { Domizi, } \\
\text { Clouser } \\
(2017)\end{array}$ & $\begin{array}{l}N=1,299 \\
\text { students }\end{array}$ & USA & $\begin{array}{l}\text { Perception } \\
\text { of } \\
\text { efficacy }\end{array}$ & $\begin{array}{l}\text { Students value the quality, } \\
\text { attributes, and cost of } \\
\text { OpenStax, specifically the } \\
\text { Biology OER }\end{array}$ \\
\hline $\begin{array}{l}\text { Yang, Li } \\
(2015)\end{array}$ & $\begin{array}{l}N=295 \\
\text { faculty }\end{array}$ & USA & $\begin{array}{l}\text { Perception } \\
\text { of } \\
\text { efficacy }\end{array}$ & $\begin{array}{l}\text { Tenured faculty tend to be } \\
\text { more engaged in open access } \\
\text { publications and the } \\
\text { adoption of open textbooks } \\
\text { for courses taught }\end{array}$ \\
\hline
\end{tabular}

Allen and Seaman's (2014) comprehensive survey of more than 3,000 faculty reported that the sampled faculty only considered cost in the textbook selection process when all other things were held equal. For this reason, it is essential for encouraging more widespread adoption to better understand not just the quality of OER but also how stakeholders view the quality of OER. For that reason, as we explored the literature, we quickly expanded the second research question to include efficacy of OER compared to traditional classroom materials as well as perception of that efficacy. Studies included represented an international perspective, but with far fewer-38\% — coming from an international sample as compared to the articles that addressed barriers and instructional strategies (Cronin, 2017; Pitt, Ebrahimi, McAndrew, \& Coughlan, 2013; Harsasi, 2015; Hussain, Chandio, \& Sindher, 2013; Kaatrakoski, Littlejohn, \& Hood, 2017; Machado, Sepúlveda, \& Montoya, 2016; McKerlich, Ives, \& McGreal, 2013; Schuwer \& Mulder, 2009).

There was a relatively even split in the literature looking at student perception of OER (Abramovich \& McBride, 2018; Bliss, Robinson, Hilton, \& Wiley, 2013; Feldstein, Martin, Hudson, Warren, Hilton III, \& Wiley, 2012; Hilton III, Gaudet, Clark, Robinson, \& Wiley, 2013; Watson, Domizi, \& Clouser, 2017) or the faculty perception of student success and efficacy in the classroom (Abramovich \& McBride, 2018; Clements \& Pawlowski, 2012; Hussain et al., 2013; Jung, Bauer, \& Heaps, 2017; Kaatrakoski et al., 2017; Pitt et al., 2013; McKerlich et al., 2013; Yang \& Li, 2015). Of these, only two (Clements \& Pawlowski, 2012; Kaatrakoski et al., 2017) found a perception of OER that was inadequate as compared to a traditional textbook or that the quality was incompatible with the course content. Otherwise, generally, faculty felt that student outcomes were equivalent when 
using OER versus traditional course materials. As for students, when awareness was brought to the course content being open, they typically viewed the quality as better than traditional materials. Additionally, Vojtech and Grissett's (2017) study demonstrated that students felt the faculty who incorporated OER were more considerate of and responsive to student needs. This financial value greatly affected student perceptions of efficacy, with many studies demonstrating that fully integrated OER resulted in significant savings whereas otherwise a student might not even purchase the course content (Abramovich \& McBride, 2018; Hilton III et al., 2013; Vojtech \& Grissett, 2017).

Some of the included articles did not ask about perceived satisfaction of OER, focusing instead on student success outcomes. These outcomes were often measured with scores on specific assignments, grades in a certain course, or overall GPA (Allen, Guzman-Alvarez, Molinaro, \& Larsen, 2015; Bliss et al., 2013; Bowen, Chingos, Lack, \& Nygren, 2012; Feldstein et al., 2012; Grewe \& Davis, 2017; Hilton III \& Laman, 2012). In each of these studies, students performed equivalently or better when OER was correctly, effectively integrated using appropriate instructional strategies. Machado et al. (2016) and Cronin (2017) suggested developing partnerships beyond the faculty departments to utilize instructional design specialty in designing, using the best practices in the open educational literature.

\section{Instructional Strategy}

By far the fewest number of studies investigated in this review addressed the third research question, highlighting the selection and design process when integrating open resources into a course. Of the 52 articles in the review, only 11 met this criteria and these are summarized below in Table 3.

Table 3: Reviewed studies by category in regard to instructional strategies $(n=11)$.

\begin{tabular}{|l|l|l|l|l|}
\hline Author & Sample Size & Country & Category & Main Findings \\
\hline $\begin{array}{l}\text { Carey, } \\
\text { Davis, } \\
\text { Ferreras, }\end{array}$ & $\begin{array}{l}N=1 \\
\text { case } \\
\text { study } \\
(2015)\end{array}$ & Canada & $\begin{array}{l}\text { Strategy; } \\
\text { reflective } \\
\text { practice }\end{array}$ & $\begin{array}{l}\text { Government-mandated open } \\
\text { projects made it easier to } \\
\text { engage faculty but multiple } \\
\text { fronts of partnership and } \\
\text { institutional support need to } \\
\text { be included to be effectively } \\
\text { integrated into campus } \\
\text { culture }\end{array}$ \\
\hline
\end{tabular}




\begin{tabular}{|c|c|c|c|c|}
\hline $\begin{array}{l}\text { Chen, Chen } \\
\text { (2010) }\end{array}$ & $\begin{array}{l}N=43 \\
\text { library } \\
\text { science } \\
\text { students }\end{array}$ & China & $\begin{array}{l}\text { Strategy; } \\
\text { problem- } \\
\text { based } \\
\text { learning }\end{array}$ & $\begin{array}{l}\text { Digital resources enhance } \\
\text { learning performance and } \\
\text { learner satisfaction when } \\
\text { engaging in PBL } \\
\text { instructional strategies and } \\
\text { activities; demonstrated } \\
\text { increase in learner } \\
\text { willingness to access and use } \\
\text { digital resources and archives } \\
\text { during e-learning }\end{array}$ \\
\hline $\begin{array}{l}\text { Elf, } \\
\text { Ossiannilsso } \\
\text { n, Neljesjö, } \\
\text { Jansson } \\
(2015)\end{array}$ & $N=26$ & Sweden & $\begin{array}{l}\text { Strategy; } \\
\text { instruction } \\
\text { al } \\
\text { integratio } \\
\mathrm{n}\end{array}$ & $\begin{array}{l}\text { The integration of OER in } \\
\text { practical coursework can } \\
\text { facilitate learning, specifically if } \\
\text { the OER is utilized by the } \\
\text { learner to self-direct the learning } \\
\text { process }\end{array}$ \\
\hline $\begin{array}{l}\text { Islim, } \\
\text { Koybasi, } \\
\text { Cagiltay } \\
(2016)\end{array}$ & $\begin{array}{l}N=710 \\
\text { students }\end{array}$ & Turkey & $\begin{array}{l}\text { Strategy; } \\
\text { suppleme } \\
\text { ntal } \\
\text { resources, } \\
\text { SRL }\end{array}$ & $\begin{array}{l}\text { Utilization of OER can promote } \\
\text { and increase the effectiveness of } \\
\text { lab experiments, increase } \\
\text { learner comprehension, and } \\
\text { contribute to a reduction in task } \\
\text { time with regard to labs; used as } \\
\text { supplemental resources in } \\
\text { preparation for the performance } \\
\text { of practical, hands-on } \\
\text { instruction directly related to } \\
\text { complex learning tasks }\end{array}$ \\
\hline $\begin{array}{l}\text { Issack } \\
\text { (2011) }\end{array}$ & $\begin{array}{l}N=3 \\
\text { case } \\
\text { studies }\end{array}$ & Mauritius & $\begin{array}{l}\text { Strategy; } \\
\text { learning } \\
\text { objects }\end{array}$ & $\begin{array}{l}\text { OERs can help build } \\
\text { sustainable educational } \\
\text { models used in universities in } \\
\text { developing countries by } \\
\text { providing a feasible and } \\
\text { viable resource at low to no } \\
\text { cost to the institutions }\end{array}$ \\
\hline $\begin{array}{l}\text { Judith, Bull } \\
\text { (2016) }\end{array}$ & $\begin{array}{l}N=20 \\
\text { case } \\
\text { studies }\end{array}$ & Australia & $\begin{array}{l}\text { Strategy; } \\
\text { reusable } \\
\text { and } \\
\text { sustainabl } \\
\text { e }\end{array}$ & $\begin{array}{l}\text { Continuum of openness } \\
\text { regarding control and } \\
\text { governance; institutional } \\
\text { policy impacts creation and } \\
\text { utilization - established } \\
\text { standards can serve to limit } \\
\text { creativity; framework for } \\
\text { establishing OER and }\end{array}$ \\
\hline
\end{tabular}




\begin{tabular}{|c|c|c|c|c|}
\hline & & & & $\begin{array}{l}\text { suggestions for } \\
\text { implementation strategies }\end{array}$ \\
\hline $\begin{array}{l}\text { Muganda, } \\
\text { Samzugi, } \\
\text { Mallinson } \\
\text { (2016) }\end{array}$ & $\begin{array}{l}N=28 \\
\text { academic } \\
\text { represent } \\
\text { atives }\end{array}$ & Tanzania & $\begin{array}{l}\text { Strategy; } \\
\text { creation } \\
\text { and } \\
\text { integratio } \\
\mathrm{n}\end{array}$ & $\begin{array}{l}\text { A comprehensive institution } \\
\text { policy is needed to guide, } \\
\text { support, encourage, and } \\
\text { promote sustainable OER } \\
\text { creation, integration, and } \\
\text { practice within college courses }\end{array}$ \\
\hline $\begin{array}{l}\text { Palmer, } \\
\text { Brimeyer, } \\
\text { Schueths } \\
(2018)\end{array}$ & $\begin{array}{l}N=275 \\
\text { general } \\
\text { OER } \\
\text { users }\end{array}$ & $\begin{array}{l}\text { Canada, Iran, } \\
\text { Malaysia, } \\
\text { Mauritius, } \\
\text { Netherlands, } \\
\text { Pakistan, } \\
\text { South Africa, } \\
\text { Sweden, UK } \\
\text { and USA }\end{array}$ & $\begin{array}{l}\text { Strategy; } \\
\text { course } \\
\text { integratio } \\
\mathrm{n} \text { and use }\end{array}$ & $\begin{array}{l}\text { Virtual teaching communities } \\
\text { designed to support collegial } \\
\text { relationships can support and } \\
\text { promote course integration of } \\
\text { OER, providing alternatives } \\
\text { to face-to-face socialization } \\
\text { of contingent faculty }\end{array}$ \\
\hline $\begin{array}{l}\text { Petrides, } \\
\text { Jimes, } \\
\text { Middleton- } \\
\text { Detzner, } \\
\text { Walling, } \\
\text { Weiss } \\
(2011)\end{array}$ & $\begin{array}{l}n_{1}=11 \\
\text { instructor } \\
\mathrm{s}, \\
n_{2}=680 \\
\text { students, } \\
n_{3}=11 \\
\text { students, } \\
n_{4}=27 \\
\text { faculty, } \\
n_{5}=34 \\
\text { students }\end{array}$ & USA & $\begin{array}{l}\text { Strategy; } \\
\text { collaborati } \\
\text { on }\end{array}$ & $\begin{array}{l}\text { Adopting OER for cost } \\
\text { savings, but OER more } \\
\text { attractive once adopted based } \\
\text { on instructional opportunities } \\
\text { (more interactive, } \\
\text { collaborative } \\
\text { teaching/learning activities); } \\
\text { mostly based around online } \\
\text { technology, which can be } \\
\text { prohibitive for students } \\
\text { uncomfortable with } \\
\text { technology }\end{array}$ \\
\hline $\begin{array}{l}\text { Visser, } \\
\text { Flynn } \\
\text { (2018) }\end{array}$ & $N=34$ & Canada & $\begin{array}{l}\text { Strategy; } \\
\text { metacogni } \\
\text { tive and } \\
\text { cognitive } \\
\text { skills }\end{array}$ & $\begin{array}{l}\text { Research indicates that an } \\
\text { online OER, created with an } \\
\text { engaging interface, may } \\
\text { promote and increase student } \\
\text { course performance; } \\
\text { participants indicated that } \\
\text { OER created with } \\
\text { multimedia promoted } \\
\text { learning and course } \\
\text { performance }\end{array}$ \\
\hline $\begin{array}{l}\text { Wiley, } \\
\text { Webb, } \\
\text { Weston, }\end{array}$ & $\begin{array}{l}n_{1}=103 \\
\text { students, } \\
n_{2}=78 \\
\text { students }\end{array}$ & USA & $\begin{array}{l}\text { Strategy; } \\
\text { arts-based } \\
\text { student- }\end{array}$ & $\begin{array}{l}\text { Student proficiency in } \\
\text { meeting course learning } \\
\text { goals increased with the }\end{array}$ \\
\hline
\end{tabular}




\begin{tabular}{|l|l|l|l|l|}
\hline $\begin{array}{l}\text { Tonks } \\
(2017)\end{array}$ & & $\begin{array}{l}\text { created } \\
\text { OER }\end{array}$ & $\begin{array}{l}\text { integration of student-created } \\
\text { OER projects }\end{array}$ \\
\hline
\end{tabular}

Even with the limited number of studies focusing on our third research question, more than $73 \%$ of the included articles were focused on OER integration strategies in international settings (Carey, Davis, Ferreras, \& Porter, 2015; Chen \& Chen, 2010; Elf, Ossiannilsson, Neljesjö, \& Jansson, 2015; Islim, Koybasi, \& Cagiltay, 2016; Issack, 2011; Judith \& Bull, 2016; Muganda, Samzugi, \& Mallinson, 2016; Visser \& Flynn, 2018).

Faculty looking to adopt OER as a replacement for traditional textbooks or course materials were much more likely to succeed when given institutional support. Ease of collaboration opportunities with other departments, allowance for faculty to take time for design and development, and financial support for professional development and training to learn best practices and deepen knowledge of remixing and open licensing options, were clear indicators in the literature that open was a part of campus culture (Carey et al., 2015; Issack, 2011; Judith \& Bull, 2016; Palmer, Brimeyer, \& Schueths, 2018). This culture was evident when OER adoption was sustainable and projects lasted longer than one semester or the length of a grant. Once faculty felt this institutional support, many took advantage of the online affordances that OER offered to produce interactive and collaborative learning activities. The multimodal open learning objects allowed for adaptability, engaging interfaces, and encouraged learner utilization for increased participation in the course (Petrides, Jimes, Middleton-Detzner, Walling, \& Weiss, 2011; Visser \& Flynn, 2018). OER was not used exclusively in online environments, though, and faculty still designed open content with student needs in mind. Practices that were particularly effective for OER integration as primary or supplemental materials were student-directed, problem-based or practical in nature, and encouraged learner self-regulation (Chen \& Chen, 2010; Elf et al., 2015; Islim et al., 2016; Wiley, Webb, Weston, \& Tonks, 2017).

\section{Dis cussion}

The present review serves to answer our initial research questions, which included barriers to OER adoption, efficacy of OER in comparison to non-open course materials, and implementation of instructional strategies that utilize OER. Of the included articles, a majority (43\%) were focused on the efficacy or perception of OER materials and the barriers to adoption (35\%). This finding paints an overarching picture that OER is generally perceived by faculty and students as being equivalent to traditional learning resources in terms of quality and that it does not negatively impact student 
learning, which is precisely in agreement with findings in alternative review studies on OER (Berti, 2018; Delgado, Delgado, \& Hilton, 2019; Hilton III, 2016). Given such understanding, the old impression that open connotes poor quality, as instructors are sacrificing the content found in paid resources in exchange for the reduction in the financial burden placed on students, should be debunked. Despite this optimistic overall landscape, researchers should continue to explore the reasoning behind limited OER adoption whilst also giving more attention to best practices at the institutional level once OER is more widely established in the classroom.

Far fewer articles $(23 \%)$ had a concentration on instructional design or strategies employed when incorporating OER. This demonstrates that the literature is interested in adoption of OER, but studies examining barriers or efficacy do not fully explore the pedagogical implications of integrating open materials into a course, or its integration at a larger program level, which also has a significant impact on adoption. It is worth noting that open educational practice (OEP), being discussed as the next phase of OER has gained traction among multiple studies (Chen \& Panda, 2013; Cronin, 2017; Kaatrakoski, Littlejohn, \& Hood, 2017; Murphy, 2013). Although the literature of OEP can be traced back to early literature where the two terms were used virtually synonymously (Geser, 2007), the most recent literature denotes OEP being a next phase of OER, where the implementation shifts from the initial stage of using open resources on a course level to considering it as an institution-wide reform of policy and culture. OEP not only encompasses the adoption of open resources but, more importantly, it embraces a dynamic discourse from a larger scope that leads to a combination of "open-oriented" practices: remixing open resources, open teaching and pedagogy, empowerment of students, as well as networked participatory scholarship (Cronin, 2017; Kaatrakoski et al., 2017; Veletsianos \& Kimmons, 2012a; Veletsianos \& Kimmons, 2012b; Stommel, 2014). For example, Wiley and Hilton (2018) promoted a notion of renewable assignments, which is an instance of OEP through which assignments are not only accomplished as evidence to show an individual student's learning, they also beget a form of sustainable open educational resources that can potentially exert a lasting impact on the broader community of learners.

We found that one of the main barriers to OER use was a lack of understanding related to open licensing options versus copyrighted resources (Anderson et al., 2017; Chen \& Panda, 2013; de Hart et al., 2015; Hassall \& Lewis, 2017; Mtebe \& Raisamo, 2014; Murphy, 2013; Panke, 2011; Rolfe, 2012; Windle et al., 2010). Additionally, discovery, storage, and future retrieval are 
problematic due to misapplication of effective metadata that would ease discoverability and sharing (Chen \& Panda, 2013; Coughlan et al., 2013; de Hart et al., 2015; Dichev et al., 2011; Robertson, 2010; Windle et al., 2010). These barriers overlap with perceptions of OER efficacy and may contribute to the limited literature focusing on instructional strategies. The repeated solutions found in the literature to address each of the research questions were institutional support and collaboration. Institutions should develop a culture of open, which requires more than a financial investmentalthough a financial investment is also needed. Professional development opportunities should emphasize digital literacy skills for both students and faculty, copyright and licensing training to clarify remixing and reuse processes; knowledge of repositories and their limitations, hands-on workshops that give faculty the time needed to create their own OER, and best practices for designing courses and activities with open multimedia content. Training meant to build a deeper understanding of OER should center on the course and curriculum learning goals and objectives. When OER fails to align with goals and objectives, open educational practices fail to enhance the educational experience for students, leading to reduced support, perceived inefficacy, and greater barriers for future adoption.

Institutional support also asks institutions of higher education to create more structured, formal policies that outline and define OER creation, use, sharing, and repurposing (Hassall \& Leiws, 2017; Machado et al., 2016; Murphy, 2013; Windle et al., 2010). OER policy not only serves to direct and facilitate OER use by faculty, by encouraging and incentivizing individuals to engage in the practice, it also demarcates what is and what may not be acceptable college practice in regards to resources, tools, and copyright. Creating structured policies would help develop incentive programs, such as faculty stipends, funding for OER integration, and course and faculty promotion. Cost will always be a major consideration for creating such institutional support. With OER's potential to reduce student instructional material costs it would be beneficial to align the financial interests of the students and of the higher learning institution using a governmental-based and institution-supported financial model for OER. From this review, it appears that mainstream adoption of institutional OER policy is not a current, consistent practice at most higher learning institutions. Based on the abovementioned discussion, we offer the following practical considerations for implementation of OER in higher education settings.

\section{Conside rations for OER Implementation}


To work toward ensuring the sustainability of OER within institutions, it is important that partnerships are established with key figures on campus, including instructional designers, e-learning staff, and academic librarians. These collaborative opportunities can aid in discoverability and selection through partnerships with the library, best practices for use and accessibility in online courses with the e-learning department, and effective instructional strategies that encourage learning by working with instructional designers. Building an infrastructure that supports this cooperation in utilizing OER not only alleviates the time commitment instructors must invest when identifying, validating, and curating OER, but also contributes to developing a process for the sustainability and maintenance of open resources (Hassall \& Lewis, 2017; Machado et al,; 2016; Murphy, 2013; Panke, 2011; Robertson, 2010; Windle et al., 2010). The obstacles to remixing can also be mitigated when experts like academic librarians who fully understand the issues around it, and are available to provide expert guidance, can step in to facilitate the process by seeking ways to addressing the potential tension between the original audience of the content and those for whom it is now intended through the remix.

Another partnership opportunity that overlaps with instructional strategies is the involvement of students in the creation, maintenance, and archiving processes of OER adoption (Wiley et al., 2017). Instructors can structure course activities that involve students working together to create their own resources, that will then be curated into an OER for future use or into an institutional repository (Warren et al., 2017). This provides students with an opportunity to develop their own instructional artifacts within a situated learning experience and to identify the gaps in current resources. Not only does this assist with the development of more accurate and up-to-date resources, it provides more autonomy to students regarding their own learning. For example, research attempted to explore the use of student assistants and instructional designers to supplement and assist faculty developers (Wiley et al., 2017).

An additional important consideration for OER implementation related to student involvement lies in the fact that students are natural citizens of the online open networks supported by social media and Web 2.0 tools such as Facebook, Twitter, YouTube, and Instagram. Hence, Dichev et al. (2011) recommended more involvement of OER users to promote open content and increase engagement with the content and interaction among users. A greater embrace of Web 2.0 functionality would allow students as OER users to tag and label content, increasing visibility and discoverability. Social media are also considered a potential tool to address challenges with 
remixing. Okada and Barros (2011) hoped to turn the remixing process back on the learner to make them actively engage with content using Web 2.0 technologies. They argued that students were comfortable with Web 2.0 technologies and, encouraged to participate by the embedded social support, the evidence demonstrated participants naturally reused the Web 2.0 tools and materials. The power of social media platforms has the potential to make a monumental impact on the way college students acquire and transfer knowledge gained from traditional course instruction into a broader scope of community network of practice in an open space. Additionally, research studies on the use of instructor-facilitated or student-led closed groups in an OER like Facebook would yield evidence-based information to support the usefulness of a specific OER function within higher education and its application with specific curriculum. This type of OER practice, originated from a course context and extended to the online social network, is also in line with the premises of OERenabled pedagogy (Wiley \& Hilton, 2018), which are unanimously recommended by scholars and practitioners.

It is important that instructors consider the purpose with regard to their potential adoption of OER. Alleviating the financial costs associated with textbooks and other instructional materials should not be the sole factor driving the use of OER in a course. Consideration must be given to what extent OER will benefit the students' learning experiences. It is also important that consideration be given as to whether OER are used as the sole resource for a course or as a supplemental resource. Ultimately, what is most important in any open educational practice is the notion of promoting the culture of openness, which extends far beyond the replacement of a proprietary textbook and expanded access to more affordable learning materials. When an instructor considers adopting OER in one course, it is crucial to consider the pedagogical implications associated with it and to foster any open educational practices that can involve student engagement.

\section{Areas for Further Research}

In addition to the studies addressing perceived effectiveness, OER efficacy is a further research area that could serve to enhance OER integration within higher education. Empirical studies on OER choice, content delivery methods, and faculty development strategies all comprehensively impact OER efficacy; little empirical data is available to prove the effective integration of these research focal points.

Policy creation and implementation at the community college level is an additional avenue of potential research for OER. As stated in Allen and Seaman's (2014) article, community colleges have 
an established history of adopting OER at higher rates than four-year institutions. And yet, of the included articles, only $18 \%$ specifically focused on community college environments (Bliss et al., 2013; Coughlan et al., 2013; Grewe \& Davis, 2017; Hilton III et al., 2013; Hilton III \& Laman, 2012; Jung et al., 2017; Murphy, 2013; Petrides et al., 2011; Pitt et al., 2013), with a majority of these articles $(67 \%)$ examining perception of open resources - two were focused on barriers to adoption and only one on instructional strategies. This unique environment is worthy of greater examination to provide better support in the research for OER efficacy in the technical and community college classroom.

Further empirical data on the ways in which institutional policy impacts faculty involvement and course integration of OER would provide more detailed information on the college administration's role in OER perception, creation, curation, and utilization, answering the ultimate question of the need for a college-wide, college-specific OER policy. Additionally, studies on faculty perception of policy implementation would provide insight into acceptance and adherence.

Lastly, we were unable to locate any existing models or frameworks for implementation referenced anywhere in the reviewed articles. We believe this was an area in which there was not significant practical guidance in the empirical, peer-reviewed literature. As there is an ongoing paradigm shift from opening up access and the availability of resources, to fostering a culture of openness at an institutional level through open educational practices, evidence-based research studies that specifically provide models of implementation and best practices for institutions, as well as for individual educational practitioners and/or learners would be extremely helpful.

\section{References}

Abramovich, S., \& McBride, M. (2018). Open education resources and perceptions of financial value. The Internet and Higher Education, 39, 33-38. doi:

https://doi.org/10.1016/j.iheduc.2018.06.002

Advisory Committee on Student Financial Assistance. (2013, September). Do no harm: Undermining access will not improve college completion. Washington, DC. Retrieved from https://www.inside highered.com/sites/default/server_files/files/Do\%20No\%20Harm.pdf

Allen, G., Guzman-Alvarez, A., Molinaro, M, \& Larsen, D. S. (2015). Assessing the impact and efficacy of the open-access ChemWiki textbook project. Paper presented at EDUCAUSE, Indianapolis, Indiana. Retrieved from https://library.educause.edu/resources/2015/1/assessing-the-impact-and-efficacy-of-the-openaccesschemwiki-textbook-project

Allen, I. E., \& Seaman, J. (2014). Opening the textbook: Educational resources in US Higher Education, 2015-16. Babson Survey Research Group. Retrieved from http:/www.onlinelearningsurvey.com/re ports/openingthetextbook2016.pdf 
Amiel, T. (2013). Identifying barriers to the remix of translated open educational resources. The International Review of Research in Open and Distributed Learning, 14(1), 126-144. doi: https://doi.org/10.19173/irrodl.v14i1.1351

Anderson, T., Gaines, A., Leachman, C., \& Williams on E. P. (2017). Faculty and instructor perceptions of open educational resources in engineering. The Reference Librarian, 58(4), 257-277. doi: https://doi.org/10.1080/02763877.2017.1355768

Berti, M. (2018). Open Educational Resources in Higher Education. Issues and Trends in Educational Technology, 6(1), 4-15.

Bliss, T. J., Robinson, T. J., Hilton, J., Wiley, D. A. (2013). An OER COUP: College teacher and student perceptions of open educational resources. Journal of Interactive Media in Education, 2013(1), 1-25.

Bowen, W. G., Chingos, M. M., Lack, K. A., \& Nygren, T. I. (2012). Interactive learning online at public universities: Evidence from randomized trials. Ithaka $\mathrm{S}+\mathrm{R}$. Retrieved from http//www.sr.ithaka.org/wp-content/uploads/2015/08/sr-ithaka-interactive-learning-onlineat-public-universities.pdf

Carey, T., Davis, A., Ferreras, S., \& Porter, D. (2015). Using open educational practices to support institutional strategic excellence in teaching, learning, and scholarship. Open Praxis, 7(2), 161-171. doi: http://dx.doi.org/10.5944/openpraxis.7.2.201

Chen, C. M., \& Chen, C. C. (2010). Problem-based learning supported by digital archives: Case study of Taiwan libraries' history digital library. The Electronic Library, 28(1), 5-28. doi: $10.1108 / 02640471011005414$

Chen, Q., \& Panda, S. (2013). Needs for and utilization of OER in distance education: A Chinese survey. Educational Media International, 50(2), 77-92. doi: 77-92, http://dx.doi.org/10.1080/09523987.2013.795324

Chiorescu, M. (2017). Exploring open educational resources for college algebra. The International Review of Research in Open \& Distributed Learning, 18(4), 50-58.

Clements, K. I., \& Pawlowski, J. M. (2012). User-oriented quality for OER: Understanding teachers' views on re-use, quality, and trust. Journal of Computer Assisted Learning, 28(1), 4-14. doi: $10.1111 / \mathrm{j} .1365-2729.2011 .00450 . \mathrm{x}$

Coughlan, T., Pitt, R., \& McAndrew, P. (2013, April-May). Building open bridges: Collaborative remixing and reuse of Open Educational Resources across organizations. In W. Mackay, S. Brewster, \& S. B $\emptyset$ dker (Eds.) CHI'13 Proceedings of the SIGCHI Conference on Human Factors in Computing Systems (pp. 991-1000). New York, NY: ACM Retrieved from http://eprints.nottingham.ac.uk/1950/1/B2S-CHI-2013.pdf

Cronin, C. (2017). Openness and praxis: Exploring the use of open educational practices in higher education. The International Review of Research in Open and Distributed Learning, 18(5), 15-34.

de Hart, K., Chetty, Y., \& Archer, E. (2015). Uptake of OER by staff in distance education in South Africa. The International Review of Research in Open and Distributed Learning, 16(2), 1845.

Delgado, H., Delgado, M., \& Hilton III, J. (2019). On the efficacy of open educational resources. The International Review of Research in Open and Distributed Learning, 20(1), 184-203.

Dichev, C., Bhattarai, B., Clonch, C., \& Dicheva, D. (2011, September). Towards better discoverability and use of open content. In D. Dicheva, Z. Markov, \& E. Stefanova (Eds,) 
Proceedings of S3T'11 Third International Conference on Software, Services and Semantic Technologies (pp. 195-203), Springer Verlag, AICS101.

Elf, M., Ossiannilsson, E., Neljesjö, M., \& Jansson, M., (2015). Implementation of open educational resources in a nursing programme: Experiences and reflections. Open Learning, The Journal of Open, Distance and e-Learning, 30(3), 252-266. doi: http://dx.doi.org/10.1080/02680513.2015.1127140

Feldstein, A., Martin, M., Hudson, A., Warren, K., Hilton III, J., Wiley, D. (2012). Open textbooks and increased student access and outcomes. European Journal of Open, Distance and E-Learning, 2, 1-9.

Friesen, N. (2009). Open educational resources: New possibilities for change and sustainability. The International Review of Research in Open and Distributed Learning, 10(5), 1-13.

Geser, G. (2007). Open Educational Practices and Resources: OLCOS Roadmap, 2012. Retrieved from http://www.olcos.org/cms/upload/docs/olcos_roadmap.pdf

Grewe, K., \& Davis, W. P. (2017). The impact of enrollment in an OER course on student learning outcomes. The International Review of Research in Open and Distributed Learning, 18(4). doi:10.19173/irrodl.v18i4.2986

Harsasi, M. (2015). The use of open educational resources in online learning: A study of students' perception. Turkish Online Journal of Distance Education, 16(3), 74-87.

Hassall, C., \& Lewis, D. I. (2017). Institutional and technological barriers to the use of open educational resources (OERs) in physiology and medical education. Advances in Physiology Education, 41(1),77-81. doi: 10.1152/advan.00171.2016.

Hew, K. F., \& Cheung, W. S. (2013, November-December). Use and production of open educational resources (OER): A pilot study of undergraduate students' perceptions. In P. Kommers, T. Issa, N. M. Sharef, \& P. Isaias (Eds.) ICEduTech 2013. Proceedings of the International Conference on Educational Technologies (pp. 125-128). IADIS Press.

Hilton III, J., Gaudet, D., Clark, P., Robinson, J., \& Wiley, D. (2013). The adoption of open educational resources by one community college math department. The International Review of Research in Open and Distributed Learning, 14(4), 1-8.

Hilton III, J., \& Laman, C. (2012). One college's use of an open psychology textbook. Open Learning: The Journal of Open, Distance ande-Learning, 27(3), 265-272. doi: http://dx.doi.org/10.1080/02680513.2012.716657

Hilton, J. (2016). Open educational resources and college textbook choices: a review of research on efficacy and perceptions. Educational Technology Research and Development, 64(4), 573590.

Hu, E., Li, Y., Li, J., \& Huang, W. H. (2015). Open educational resources (OER) usage and barriers: A study from Zhejiang University, China. Educational Technology Research Development, 63(6), 957-974. doi: 10.1007/s11423-015-9398-1

Hussain, I., Chandio, J. H., \& Sindher, R. H. K. (2013). A study on attitude of university academia towards the use of open educational resources in higher education. Pakistan Journal of Commerce and Social Sciences, 7(2), 367-380.

Islim, O. F., Koybasi, N. A. G., \& Cagiltay, K. (2016). Use of open educational resources: How, why and why not? International Journal of Teaching and Learning in Higher Education, 28(2), 230-240.

Issack, S. M. (2011). OERs in context - case study of innovation and sustainability of 
educational practices at the University of Mauritius. European Journal of Open, Distance and E-Learning, 1, 1-10.

Judith, K, \& Bull, D. (2016). Assessing the potential for openness: A framework for examining course-level OER implementation in higher education. Education Policy Analysis Archives, 24(42), 1-16. doi: http://dx.doi. org/10.14507/epaa.24.1931

Jung, E., Bauer, C., \& Heaps, A. (2017). Higher education faculty perceptions of open textbook adoption. The International Review of Research in Open and Distributed Learning, 18(4), 123-141.

Kaatrakoski, H., Littlejohn, A., \& Hood, N. (2017). Learning challenges in higher education: An analysis of contradictions within open educational practice. Higher Education, 74(4), 599615. doi: 10.1007/s10734-016-0067-z

Machado, M. S. P., Sepúlveda, G. C. T., \& Montoya, M. S. R. (2016). Educational innovation and digital competencies: The case of OER in a private Venezuelan university. International Journal of Educational Technology in Higher Education, 13(10), 1-10. doi: 10.1186/s41239016-0006-1

McKerlich, R., Ives, C., \& McGreal, R. (2013). Measuring use and creation of open educational resources in higher education. The International Review of Research in Open and Distributed Learning, 14(4), 90-103. doi:http://dx.doi.org/10.19173/irrodl.v14i4.1573

Mtebe, J. S., \& Raisamo, R. (2014). Investigating perceived barriers to the use of open educational resources in higher education in Tanzania. The International Review of Research in Open and Distributed Learning, 15(2), 43-65.

Muganda, C. K., Samzugi, A. S., \& Mallinson, B. J. (2016). Analytical insights on the position, challenges, and potential for promoting OER in OdeL institutions in Africa. International Review of Research in Open and Distributed Learning, 17(4), 36-49.

Murphy, A. (2013). Open educational practices in higher education: Institutional adoption and challenges. Distance Education, 34(2), 201-217. doi: https://doi.org/10.1080/01587919. 2013.793641

Ngimwa, P., \& Wilson, T. (2012). An empirical investigation of the emergent issues around OER adoption in Sub-Saharan Africa. Learning, Media and Technology, 37(4), 398-413. doi: https://doi.org/10.1080/17439884.2012.685076

Okada, A., \& Barros, D. (2011, June-July). Using, adapting and authoring OER with Web 2.0 tools. In T. Bastiaens, \& M. Ebner (Eds.) ED-MEDIA 2011. Proceedings of the World Conference on Educational Multimedia, Hypermedia and Telecommunications (pp. 2243-2248). Lisbon, Portugal: Association for the Advancement of Computing in Education (AACE). Retrieved from https://www.learntechlib.org/primary/p/38171/.

Palmer, N., Brimeyer, T., \& Schueths, A. M. (2018). Do open educational resources help contingent sociology faculty acquire teaching resources and form collegial relationships? The American Sociologist, 49(1), 119-134.

Panke, S. (2011, June-July). Open educational resources: Future directions for research and practice. In T. Bastiaens, \& M. Ebner (Eds.) ED-MEDIA 2011 Proceedings of the World Conference on Educational Multimedia, Hypermedia and Telecommunications (pp. 1429-1438). Lisbon, Portugal: Association for the Advancement of Computing in Education. Retrieved from https://www.learntechlib.org/p/38053

Petrides, L., Jimes, C., Middleton-Detzner, C., Walling, J., \& Weiss, S. (2011). Open textbook adoption and use: Implications for teachers and learners. Open Learning, The Journal of Open, Distance and e-Learning, 26(1), 39-49. doi: 10.1080/02680513.2011.538563 
Pitt, R., Ebrahimi, N., McAndrew, \& P., Coughlan, T. (2013). Assessing OER impact across organisations and learners: Experiences from the Bridge to Success project. Journal of Interactive Media in Education, 2013(3), 1-34. doi: http://doi. org/10.5334/2013-17

Popken, B. (2015, August 6). College textbook prices have risen 1,041 percent since 1977. NBC News. Retrieved from http://www.nbcnews.com/feature/freshman -year/college-textbook-prices-have-risen-812-percent-1978-n399926

Robertson, R. J. (2010, November). What do academic libraries have to do with Open Educational Resources? Long term sustainability of open education projects. In Open Ed 2010 Proceedings. Barcelona, Spain: UOC, OU, BYU. Retrieved from http://hdl.handle.net/10609/4847

Rolfe, V. (2012). Open educational resources: Staff attitudes and awareness. Research in Learning Technology, 20, 1-14. doi: 10.3402/rlt.v20i0/14395

Schuwer, R., \& Mulder, F. (2009). OpenER, a Dutch initiative in open educational resources. Open Learning: The Journal of Open, Distance and e-Learning, 24(1), 67-76. doi: $10.1080 / 02680510802627852$

Stommel, J. (2014). Critical digital pedagogy: a definition. Hybrid Pedagogy. Retrieved from http:/www.digitalpedagogylab.com/hybridped/critical-digital-pedagogy-definition/

UNESCO (2002, July). Forum on the impact of open courseware for higher education in developing countries: Final report. Retrieved from http://unesdoc.unesco.org/images/0012/001 285/ 128515e.pdf

Veletsianos, G., \& Kimmons, R. (2012a). Assumptions and challenges of open scholarship. The International Review of Research in Open and Distance Learning, 13(4), 166-189. doi:10.19173/irrodl.v13i4.1313

Veletsianos, G., \& Kimmons, R. (2012b). Networked participatory scholarship: Emergent technocultural pressures toward open and digital scholarship in online networks. Computers \& Education, 58(2), 766-774. doi:10.1016/j.compedu.2011.10.001

Visser, R., \& Flynn, A. B. (2018). What are students' learning and experiences in an online learning tool designed for cognitive and metacognitive skill development? Collect Essays on Learning and Teaching, 11, 129-140.

Vojtech, G., \& Grissett, J. (2017). Student perceptions of college faculty who use OER. The International Review of Research in Open and Distributed Learning, 18(4).

Warren, J. W., Dunaway, S., Matthews, J., Johnston, J., Hoy, V., \& Saunders, C. (2017, June). Open educational resources (OERs) part 2: Collaborating and developing OERs for your courses. In Innovations in Teaching \& Learning Conference Proceedings (Vol. 9).

Watson, C. E., Domizi, D. P., \& Clouser, S. A. (2017). Student and faculty perceptions of OpenStax in high enrollment courses. International Review of Research in Open and Distributed Learning, 18(5), 287-304.

Wiley, D., \& Hilton III, J. L. (2018). Defining OER-enabled pedagogy. The International Review of Research in Open and Distributed Learning, 19(4), 133-147.

Wiley, D., Webb, A., Weston, S., \& Tonks, D. (2017). A preliminary exploration of the relationships between student-created OER, sustainability, and students success. International Review of Research in Open \& Distributed Learning, 18(4), 60-69.

Windle, R. J., Wharrad, H., McCormick, D., Laverty, H., \& Taylor, M. (2010). Sharing and reuse in OER: Experiences gained from open reusable learning objects in health. Journal of Interactive Media in Education, 33(1), 1-19. doi: http://doi.org/10.5334/2010-4

Yang, Z., Y., \& Li, Y. (2015). University faculty awareness and attitudes towards open access 
publishing and the institutional repository: A case study. Journal of Librarianship and Scholarly Communication, 3(1), 1-31. doi: http://dx.doi.org/10.7710/2162-3309.1210 